\title{
SEARCHING FOR LEGITIMACY? \\ THE MOTIVATIONS BEHIND INTER-KOREAN DIALOGUE DURING THE MID-1980s
}

\author{
Stephen Ranger ${ }^{1}$ \\ European Centre for International Political Economy
}

\begin{abstract}
Throughout the history of inter-Korean relations, the process of engagement between 1984 and 1985 has been of little focus among studies. Yet it is worthy of close analysis as it occurred during a critical time when Cold War tensions were mounting with shifts in the balance of power between the Soviet Union and the United States as well as the upcoming Summer Olympics in Seoul. This article reveals the way in which the complex international environment shaped inter-Korean dialogue, particularly within the context of how each side was also seeking support from the Soviet Union. Crucially, it will show that inter-Korean dialogue formed an important source of legitimacy for the two Koreas, both domestically and internationally. This has ramifications for today where the two Koreas are seeking out contacts with one another within a regional order increasingly being shaped by China.
\end{abstract}

Keywords: Inter-Korean relations, South Korea, North Korea, nationalism, Cold War

Título en Castellano: ¿Buscando legitimidad? Las motivaciones detrás del Diálogo Intercoreano a mediados de la década de 1980

\section{Resumen}

En la historia de las relaciones intercoreanas, se ha prestado poca atención en los estudios al proceso de interacción y compromiso llevado a cabo en 1984 y 1985. Sin embargo, es digno de un análisis minucioso, ya que ocurrió durante un momento crítico en el que las tensiones de la Guerra Fría estaban aumentando con cambios en el equilibrio de poder entre la Unión Soviética y los Estados Unidos, teniendo en cuenta los próximos Juegos Olímpicos de Seúl. Este artículo revela la forma en que el complejo entorno internacional dio forma al diálogo intercoreano, particularmente contemplando cómo cada parte también estaba buscando el apoyo de la Unión Soviética. Mostrará de forma crucial que el diálogo intercoreano constituyó una importante fuente de legitimidad para las dos Coreas, tanto a nivel nacional como internacional. Todo esto tiene derivaciones hoy en día, donde las dos Coreas están buscando contactos entre sí en un orden regional que está siendo moldeado cada vez más por China.

Palabras Clave: Relaciones intercoreanas, Corea del Sur, Corea del Norte, nacionalismo, Guerra Fría.

Copyright @ UNISCI, 2019.

Las opiniones expresadas en estos artículos son propias de sus autores, y no reflejan necesariamente la opinión de UNISCI. The views expressed in these articles are those of the authors, and do not necessarily reflect the views of UNISCI

\footnotetext{
${ }^{1}$ Stephen Ranger is a Research Associate at the European Centre for International Political Economy (ECIPE) and PhD Candidate at Centre of East Asian Studies, University of Turku, Finland.

E-mail: <stephen.ranger@ecipe.org>

DOI: http://dx.doi.org/10.31439/UNISCI-72
} 


\section{Introduction}

How does legitimacy play a role in inter-Korean relations? And what happens when the international environment has an impact upon this? While the two Koreas always exalt declarations of reunification and peace, to what extent do contacts with the other side shape the way in which they view their position on the Korean Peninsula. Crucially, what does this tell us about inter-Korean relations going forward? This article utilizes the example of inter-Korean engagement during the mid-1980s. In this respect, it considers how changes in the international environment had an impact on decisions made and the choice to engage with one another. To understand the great changes that happened during this period it is important to reflect on some of the remarkable events that occurred before.

On 9 October, 1983, South Korean President Chun Doo-hwan narrowly avoided an assassination attempt by North Korea during a state visit to Myanmar. His late arrival to a ceremony at the Martyrs Mausoleum spared his life, but the bomb intended to kill him still took out much of his administration who were in attendance. The explosive device had been planted by North Korean agents who were subsequently arrested before they could escape the country. ${ }^{2}$ On the hurried presidential flight back to South Korea, one prominent business figure who was part of the official delegation suggested to Chun that they should set up a charitable foundation to help families of the victims. Known as the Ilhae Foundation, this fund would go on to become the focal point of corruption scandals surrounding Chun and his family as well as an example of how his administration used the North Korea threat to profit and create fear. ${ }^{3}$ Surprisingly, the day before the bombing, United States (US) officials received a message from North Korea expressing a willingness to participate in three-way talks involving South Korea as a full participant. ${ }^{4}$ This episode sums up the many complexities surrounding inter-Korean relations, the role and influence of foreign powers, as well as the impact of domestic politics.

Two years after this episode, Chun Doo-hwan would welcome senior delegates from North Korea in the first high-level exchange between the two Koreas since the flurry of engagement in 1972. This was the culmination of proactive diplomatic activities by each side and began when North Korea offered aid to South Korea following major floods in the country in September 1984. This kicked off various exchanges where high-level officials paid visit to each other's capital and met with the leaders of the two Koreas. Finally in September 1985, both Koreas agreed to hold family reunions for the first time since the end of the Korean War. While this was a successful breakthrough, further progress broke down in $1986 .{ }^{5}$

The diplomatic path that led to this engagement sheds much light on the way in which the two Koreas have pursued dialogue and its relationship with their own sense of national identity as well as their existence in a region dominated by larger powers. Although this occurred three decades ago and during the Cold War, its implications and relevance for the current wave of contacts between Kim Jong-un and Moon Jae-in are noteworthy, particularly in the context of changes in US-China relations.

The period up to the mid-1980s was a time of great change in the two Koreas and more broadly in the international environment. The military government under Chun Doo-hwan was facing many domestic challenges following its seizure of power through a military coup in 1979. In response to growing discontent with authoritarian rule, the Chun administration relied upon sustained economic growth and the hosting of the Olympics. North Korea for its part was

\footnotetext{
${ }^{2}$ Oberdorfer, Don. (1997): The Two Koreas: A Contemporary History, London, Little, Brown, pp. 140-143.

${ }^{3}$ Clifford, Mark. (1998): Troubled Tiger: Businessmen, Bureaucrats and Generals in South Korea, Armonk, M.E. Sharpe, pp. 194-199.

${ }^{4}$ Oberdorfer, op. cit., p. 144.

${ }^{5}$ Oberdorfer, op. cit., p. 148.
} 
undergoing a delicate process of leadership transition for the first time in its history. At the Sixth Congress of the Korean Worker's Party held in 1980, Kim Il-sung formally named his son Kim Jong-il as his successor. Internationally, the Cold War was entering a phase of heightened tensions as both the United States and the Soviet Union feared the intentions of the other. At the same time, Washington was reaching out to Beijing in the hope of enhancing ties.

Given this context, what motivations were there for the two Koreas to begin a process of dialogue? How were the motivations strong enough that South Korea could overcome the direct threat posed by North Korea in 1983 with the Rangoon bombing? At the same time, why did North Korea feel the need to reach out to the Chun administration that it bitterly opposed and hoped would collapse in face of strong domestic opposition? In answering these questions and producing a framework on how the talks emerged, this article will show the way in which the two Koreas conceived of their respective national identity. In a comparative exercise, it will be compared with the current process of inter-Korean talks which have advanced but also encountered limitations.

To explore this topic, this article consists of the following sections. The first considers the literature on the topic and its limitations, the second explores the motivations for talks based on areas mentioned in the literature, the third debates some of the points from this study and the current round of inter-Korean engagement, and the last part sums up the main points in the conclusion.

\section{Literature Review}

The literature on inter-Korean relations has been broad as might be expected, but the majority has focused on the Sunshine Policy and recent developments related to the North Korean nuclear issue. Even those of a historical perspective have tended to gloss over the period of inter-Korean engagement during the mid-1980s, particularly from the international context.

One of the few to have examined this period is the work by Don Oberdorfer. His insider account provides important details on how the talks were able to come about and the key persons involved. ${ }^{6}$ For the period during the mid-1980s, he considers more on the motivations for North Korea to initiate talks. In this respect he presents three hypothesis, the first is that the talks were initiated as a divisionary tactic in the event that the Rangoon bombing failed as it did, the second is that this process was undertaken by elements within the North Korean regime who were unaware of the bomb plot, and the third is that the disjointed policy approaches reflected internal discord in the regime. Oberdorfer disputes these hypotheses and instead believes that it is more likely that North Korea was pursuing both policies on different tracks. ${ }^{7}$ This is a plausible idea, but explains more the method adopted rather than the motivation and overall policy objectives.

Explanations for the two Korea's motivations can be extrapolated from different periods that have been studied. In examining the Yushin regime that was installed by South Korean President Park Chung Hee in October 1972, Im highlights the origins and decisions behind the choice to install this dictatorial system in which all power was placed in Park's hands. ${ }^{8}$ In particular, he addresses the process of inter-Korean ties during this period and its linkages with domestic political changes in both North and South Korea as well as the uncertain international climate as a result of détente and President Richard Nixon's visit to China in 1972. It is

\footnotetext{
${ }^{6}$ Ibid.

${ }^{7}$ Ibid., p. 145.

${ }^{8}$ Im, Hyung Baeg: “The Origins of the Yushin Regime: Machiavelli Unveiled”, in Vogel, Ezra F. and Kim, ByungKook (eds.) (2011): The Park Chung Hee Era: The Transformation of South Korea, Cambridge, Harvard University Press, pp. 254-255.
} 
interesting to see how both Koreas feared these international changes and the concern that their future would be potentially determined by the great powers without their consent.

The other domestic motivation that Im identifies is related to how both Park Chung Hee and Kim Il-sung sought to solidify their own power base. In this case, inter-Korean dialogue provided a positive and future-orientated policy to offset the negative consequences from the implementation of more authoritarian policies. Still, these achievements came to nothing as both sides backed away quietly having successfully consolidated power in each respective capital. As Im mentions, for Park and presumably Kim as well, inter-Korean dialogue was a double-edged sword. On the one hand they wanted closer ties to promote a more positiveorientated policy that showed they were working for unification, at the same time both sides required the other to be a present threat in order to justify their authoritarian rule. Such a quandary would manifest itself again in the mid-1980s.

Paik has provided an overview of inter-Korean relations from 1991 to 2012, basically covering the period of Kim Jong-il's rule. ${ }^{9}$ In his overall assessment, he states that North Korea's general policy to the South did not change much during this time and was rather more focused on its own survival strategy that characterized the post-Cold War environment. What did change though were the tactics and methods employed. He mentions that the process resembled a rollercoaster trajectory and in some ways reflected the policy differences between the successive administrations in South Korea.

What Paik's study shows is that domestic politics in South Korea have a major effect on the way in which talks are pursued and how North Korea responded. By contrast, for North Korea, a difficult international environment or a shift in the balance of power often pushes it to work with South Korea. Furthermore, what is clear from both Im and Paik is that leadership changes in North Korea have had a significant impact on inter-Korean ties. In the early 1970s the motivational factor was the constitutional changes and the implementation of the Suryong system which institutionalized the supreme rule of Kim Il-sung. During the early 2010s, Kim Jong-un's emergence as successor to his father had a number of effects on inter-Korean ties. The situation in the mid-1980s though would be more complex in terms of the impact of leadership transition. Here it is worth examining the international environment, something under looked in the literature, at the time and the way in which it exerted pressures on the two Koreas as will be explored in the next section.

\section{Motivations for talks}

The international context has been recognized as an important factor in inter-Korean relations but has not been applied much in the case of the period of engagement in the mid-1980s. In a general sense, the literature on international relations theories that have examined East Asia tend to consider the bipolar structure of the Cold War as dominating the region. Yet the literature has not considered much about changes that took place, both in the 1970s with détente and the mid-1980s with the shifting power balance between the United States and the Soviet Union.

These points are examined in the following sections that help to understand the motivations for talks. The first considers the international environment and changes in the balance of power, while the second and third parts seek to understand the motivations for North Korea and South Korea respectively toward engaging in talks within this context. For North

\footnotetext{
${ }^{9}$ Paik, Haksoon: "Changes and Continuities in Inter-Korean Relations", in Snyder, Scott and Park, Kyung-Ae (eds.) (2013): North Korea in Transition: Politics, Economy, and Society, Lanham, Rowman and Littlefield Publishers, pp. 239-260.
} 
Korea, its relations with the Soviet Union had an impact while for South Korea domestic factors and the hosting of the Olympics were strong factors.

\subsection{A dangerous international environment}

The mid-1980s was a period that marked heightened tensions between the United States and the Soviet Union. In particular when the United States and its allies held the Able Archer military exercise in 1983, the realistic conditions created fears in the Kremlin that it was a cover for an actual nuclear strike against its territory. ${ }^{10}$ This was arguably a period in which the prospect of nuclear war was closer than at any time since the Cuban Missile Crisis of 1962. It has only been in last few years that documents from the Soviet Union have revealed how close the world came to the brink. ${ }^{11}$ In understanding why tensions reached such a crescendo, many observers point to the election of Ronald Reagan and the growing paranoia in the Kremlin as reasons for why the situation reached such dangerous levels. ${ }^{12}$ However, structural factors actually shaped the policies in the two countries. By the 1980s, the power disparity between the United States and the Soviet Union was growing which created the paranoia and sense of vulnerability within the Kremlin and the confidence and forceful policies exhibited by the White House. ${ }^{13}$ This dangerous environment exerted a number of pressures on the two Koreas. For South Korea, it created a siege-like atmosphere while in North Korea there was concern about the shifting balance of power, particularly in relation to its traditional ally China which was turning to the United States.

Between March and April 1983, the United States Navy undertook the largest exercise in its history in the Northwest Pacific. As part of the exercise, US naval aircrafts conducted secret overflights of Soviet territory exposing gaps in the air defences, which induced worries in the Kremlin about its military readiness. It was out of this fear of weakness that the Soviet military shot down a Korean airliner that had mistakenly overflown the Soviet Union in September 1983. ${ }^{14}$ Together with the Rangoon bombing in October of the same year, the situation in South Korea was of great fear. Facing such threats, it might be expected that South Korea would engage in balancing acts against North Korea and the Soviet Union such as strengthening its alliance further with the United States or building up its own military strength. While to a limited extent this happened, the Chun administration still pursued dialogue.

North Korea had its own fears, certainly the major naval exercises in the Northwest Pacific would have alarmed them. However, of greater concern was the shifting balance of power in the region. Throughout its history, Pyongyang had been able to balance between Moscow and Beijing. ${ }^{15}$ But as tensions increased between the Soviet Union and the United States in the early 1980s, North Korea was worried about reforms taking place in China. The suspicions within the North Korean leadership focused on whether this would orientate it more toward the United States. ${ }^{16}$ Such a worry became more evident with the announcement of Reagan's visit to China for April 1984. In this respect, one can see parallels with the early 1970s

\footnotetext{
${ }^{10}$ Hoffman, David. (2009): The Dead Hand: The Untold Story of the Cold War Arms Race and Its Dangerous Legacy, New York, Anchor Books, pp. 60-100.

${ }^{11}$ Barrass, Gordon: “Able Archer 83: What Were the Soviets Thinking?”, Survival, Vol. 58, nº 6 (November 2016), pp. 7-30.

${ }^{12}$ Sebestyen, Victor. (2009): Revolution 1989: The Fall of the Soviet Empire, London, Weidenfeld \& Nicholson, pp. 79-94

${ }^{13}$ Allen, Robert C: "The Rise and Decline of the Soviet Economy", The Canadian Journal of Economics / Revue Canadienne D'Economique, Vol. 34, no 4, (November, 2001), pp. 859-81.

${ }^{14}$ Hoffman op. cit., pp. $72-88$

15 Tertitskiy, Fyodor: "How Kim Il Sung broke free from the Soviet Union,” NK News, March 19, 2019.

${ }^{16}$ Ming, Liu: "Changes and Continuities in Pyongyang's China Policy", in Snyder, Scott and Park, Kyung-Ae (eds.) (2013): North Korea in Transition: Politics, Economy, and Society, Lanham, Rowman and Littlefield Publishers, p. 218; Oberdorfer, op. cit., p. 218.
} 
when President Richard Nixon's visit to China shocked the two Koreas and drove them to hold talks in $1972 .{ }^{17}$ Therefore, the structural conditions here provide some explanation but the approaches between the two Koreas need to be explored more from the perspective of each side.

\subsection{North Korea's motivations}

North Korea enjoyed a unique position in the communist world. It had been established as a puppet state of the Soviet Union yet had managed to pursue an independent path by the $1960 \mathrm{~s}^{18}$ Throughout much of the Cold War, Pyongyang was very skilful in balancing its relations with Beijing and Moscow by playing each side against the other. ${ }^{19}$ However, changes in the international environment placed this approach in difficulty as China sought closer ties with the United States while relations with the Soviet Union became more distant throughout the 1970s, this was also reflected in declining trade between the two countries. In the mid-1980s, Kim Ilsung would push ahead with renewed efforts to improve ties with Moscow by undertaking a personal visit to the Soviet Union. Two key motivations lay behind the trip. The first was in acquiring economic and military aid at a time when trade was in decline and the second was in convincing the Soviet Union not to recognize South Korea. ${ }^{20}$

Acquiring economic and military aid from the Soviet Union became a paramount objective for North Korea in the 1980s as its economy was in a weakened state. Although, it had enjoyed a relatively strong performance throughout the 1960 s, by the mid-1970s the situation became worse. North Korea had defaulted on its international debts which meant it was now fully reliant upon the Soviet Union for economic support. ${ }^{21}$ Alongside this, the military balance on the Korean Peninsula was shifting slowly in South Korea's favour as the Chun administration was about to acquire the latest generation fighter jets from the United States. ${ }^{22}$ Furthermore, the South Korea-US militaries were conducting regular joint exercises which had been initiated in the late-1970s. For North Korea, these were viewed as a dressrehearsal for an invasion of its territory.

Facing such a new threat, it was vital that North Korea received the latest military equipment from the Soviet Union. Despite the keen demand within Pyongyang, Moscow was sensitive about the provision of military equipment and whether it would be used as part of an invasion of South Korea. Eventually, North Korea agreed to concessions in exchange for military aid. First, North Korea allowed Soviet military aircrafts to fly over its territory and naval vessels to dock at its ports. For a country priding itself on an independent path, this was a notable concession, particularly as it upset China who viewed it with great suspicion. ${ }^{23}$ Second, in exchange for nuclear technology assistance, North Korea had to join the NonProliferation Treaty and abide by its safeguards which included inspections. ${ }^{24}$

One can see here that North Korea's contacts with South Korea during this period were part of these concessions, or a way to appease the concerns Moscow held about Kim Il-sung

\footnotetext{
${ }^{17}$ Ibid., pp. 27-46

18 Tertitskiy, op. cit.

${ }^{19}$ Buzo, Adrian. (1999): The Guerrilla Dynasty: Politics and Leadership in North Korea, London, I.B. Tauris, p. 148.

${ }^{20}$ Oberdorfer, op. cit., p. 157.

${ }^{21}$ Eberstadt, Nicholas: "Western Aid: The Missing Link for North Korea's Economic Revival", in Snyder, Scott and Park, Kyung-Ae (eds.) (2013): North Korea in Transition: Politics, Economy, and Society, Lanham, Rowman and Littlefield Publishers, pp. 129-130.

${ }^{22}$ Oberdorfer, op. cit., p. 157.

${ }^{23}$ Ibid., p. 157.

${ }^{24}$ Lankov, Andrei. (2013): The Real North Korea: Life and Politics in the Failed Stalinist Utopia, Cambridge, Cambridge University Press, p. 148.
} 
receiving military equipment and nuclear assistance. It is interesting though how this does contradict with the other primary purpose of the North Korean trip, namely to persuade Moscow to cut of its contacts with Seoul, particularly with its hopes for a boycott of the Olympics. As always though, inter-Korean ties formed something of a double-edged sword. It was difficult for North Korea to argue for the Soviet Union to cut off ties when Kim Il-sung himself was meeting with South Korean officials. ${ }^{25}$

\subsection{South Korea's motivations}

In the aftermath of the assassination of South Korean President Park Chung-hee, Major-General Chun Doo-hwan seized power in a military coup launched on 12 December 1979. A year later in the provincial city of Kwangju, his troops brutally put down an uprising against his seizure of power, an action that marked a bloody stain on his rule. Given the way in which he had gained power, it was imperative that Chun produce achievements that would justify the measures taken, his focus therefore was on economic development and the hosting of the Olympics.

It was in this climate that North Korea launched its diplomatic offensive in the mid1980s. Their primary aim was to co-host the Olympics with Seoul and was backed by the International Olympic Committee (IOC) who sought to sponsor talks between the two Koreas. When confronted with this proposal for co-hosting the Olympics, the Chun administration did not reject them outright and in fact agreed to talks. ${ }^{26}$ In many ways this IOC-sponsored dialogue formed a parallel track to the engagement efforts on the Korean Peninsula.

The Olympic Committees of both Koreas met a number of times in October 1985 to discuss plans for how North Korea could participate in the games. Throughout the discussions, ideas were put forward that North Korea could host a few events for some minor games as well as a proposal that both Koreas enter the opening ceremony as a joint team. ${ }^{27}$ None of these suggestions managed to gain much momentum and North Korea's bargaining power weakened when in January 1986, the Soviet Union announced that it would not support any boycott of the games and would be fully participating along with its East Bloc allies. ${ }^{28}$ It should be noted here that South Korea needed to win the support of Moscow and its allies, therefore engaging North Korea would not only appease their concerns but also help boost the legitimacy for Chun's regime in both the domestic and international setting.

It is interesting that as these talks were going on in Switzerland, inter-Korea contacts were ramping up. In September 1985, the two Koreas permitted the meeting of separated families from each side. High-level dialogue was also taking place behind the scenes. Former North Korean foreign minister Ho Dam and special envoy Han Se Hae visited South Korea and met with Chun Doo-hwan in September 1985. A reciprocal visit took place the following month when South Korea's intelligence chief Chang Se Dong and special emissary Park Chul Un visited Pyongyang in the hopes of arranging an inter-Korean leadership summit. However, the outcome of this visit was not so successful and disputes arose over the wording of the agreements to be signed. Ties would break down completely in early 1986 as North Korea backed away in the face of the South Korea-US Team Spirit military exercises.

\footnotetext{
${ }^{25}$ Oberdorfer, op. cit., p. 157.

${ }^{26}$ Ibid. p. 181-182; see also Meeting between the National Olympic Committees of the ROK and of the DPRK held under the Aegis of the International Olympic Committee, at https://digitalarchive.wilsoncenter.org/document/113455.

${ }^{27}$ Ibid.

${ }^{28}$ Oberdorfer, op. cit., p. 182.
} 
By mid-1987, it was evident that the proposals for North Korea to host a few events was an outcome that would not be acceptable for Pyongyang. ${ }^{29}$ With little prospect for an international boycott or participation under acceptable terms, North Korea turned to terrorism as its agents detonated a bomb on a Korean airliner over the Indian Ocean in October $1987 .{ }^{30}$ In fact, North Korea had undertaken a similar action when its agents planted a bomb in Kimpo Airport as part of an effort to disrupt the Asian Games in $1986 .{ }^{31}$ Both cases show how desperate and sensitive North Korea was to these international sporting events, particularly given the participation of its allies. In the case of the Asian Games, China participated, while for the Olympics, the Soviet Union and other East Bloc countries refused to engage in a boycott. To overcome this international embarrassment, North Korea would go on to host the World Festival of Youth and Students Games in 1989. The sheer amount spent for hosting the games, a quarter of its overall budget for the year, is evident of the value North Korea placed on such international prestige events and the bitterness it felt over the Seoul Olympics. ${ }^{32}$

\section{Discussion: Implications for current talks}

Although often overlooked in the history of inter-Korean ties, the case example of contacts during the mid-1980s hold some important lessons and implications that are relevant for today. The Soviet Union is long gone now, however the region continues to be dominated by great power rivalry in the shape of US-China relations. The way in which the two Koreas interacted with the Soviet Union in the past is an interesting analogy with how they manage their relations with China today.

Looking at inter-Korean ties in 2019, President Moon Jae-in is seeking to promote the goals of peace and reunification and this forms his mandate for engagement. Yet at the same time, he has strong domestic concerns that push him to seek achievements with North Korea. Given the economic difficulties he is faced with and the troubles in launching his economic plans, North Korea remains an attractive option for presenting a success story. Furthermore, he is also looking at enhancing ties with China which correlate with pursuing positive ties with North Korea.

Kim Jong-un for his part may fear the consequences of Trump's unpredictable foreign policy, particularly when the prospects for war seemed high in 2017 over the nuclear issue (Van Jackson 2019), yet he is also seeking to gain greater international legitimacy for his regime and balance against overdependence on China's economic investment. ${ }^{33}$ Such an approach attempts to normalize his nuclear program and weaken the international sanctions regime in place against North Korea. ${ }^{34}$ It should not be overlooked here that North Korea is indeed concerned about its international image and is not always the belligerent state that does not care about how it is portrayed.

In this respect, it is important to understand the fundamentals of the Korean War and why the two sides fought each other as well as the broader issues. The war that broke out in 1950 was never about one cause, nor did it come out of the blue on June 25. This is crucial toward understanding the prospects for inter-Korean dialogue and whether it can solve conflict on the Korean Peninsula and help toward reunification. Daniel Pinkston has stated that when

\footnotetext{
${ }^{29}$ Ibid., p. 182.

${ }^{30}$ Wingfield-Hayes, Rupert: “The North Korean Spy who Blew up a Plane”, BBC News, 22 April, 2013.

${ }^{31}$ Jameson, Sam: "Bomb Kills 5 in Seoul; North Koreans Blamed”, Los Angeles Times, September 15, 1986.

${ }^{32}$ Kristof, Nicholas: "North Korea Bids Hello to the World", New York Times, July 1, 1989; Oh, Kangdon: "North Korea's Response to the World: Is the Door Ajar?", Rand Corporation, (January 1990), at https://www.rand.org/pubs/papers/P7616.html.

${ }^{33}$ Jackson, Van. (2018): On the Brink: Trump, Kim, and the Threat of Nuclear War, Cambridge, Cambridge University Press.

${ }^{34}$ Lewis, Jeffrey: “North Korea's Nuclear Disappearing Act”, National Interest, September 10, 2018.
} 
talking about ending the Korean War, it is not just about North and South or the North and the US, but also involves China. ${ }^{35}$ Given the international factors that have always been relevant, it is clear that inter-Korean talks by themselves can only achieve so much and helps to understand why they so often break down.

\section{Conclusion}

Viewed in isolation, the motivations for inter-Korean dialogue in the mid-1980s can be difficult to interpret and thus its relevance is often disregarded. It is obvious that South Korea was led by a military government which was guided by strong anti-communist policies, but why did it engage in talks? The decision to initiate dialogue from 1984 is even more curious given the fact that North Korea had attempted to assassinate Chun Doo-hwan the year before. North Korea was very much hostile to the Chun administration and would have avoided any gestures that would lend him legitimacy either internationally or domestically, why then did it agree to the reunion of separated families?

Changes in the international environment provide an important context as the two Koreas faced challenges with transformation in the balance of power in the Cold War context. The Olympic factor is also very important here in understanding why these contacts happened. This prestigious sporting event brought about a great challenge for each side's sense of legitimacy. It should be noted that neither country was a member of the UN at the time (both would only join in 1991). The Olympics presented the Chun administration with a domestic rationale for harsh rule, a feel good factor for a weary population, and a political boost for the presidential elections slated to be held after the games. North Korea on the other hand had much to lose, its allies were likely to participate thus undercutting its legitimacy among the communist world at a time when questions were raised about its process of hereditary succession, with some accusing it of nepotism. As a result, both were reaching out to the Soviet Union in different ways while engaging in dialogue with one another.

While the Olympic factor was a critical variable that changed the dynamics on the Korean Peninsula, this period of diplomacy was made easier by two conditions. For South Korea, growing domestic opposition as well as a more compromising Soviet Union pushed the Chun administration to seek out positive inter-Korean ties. By contrast, North Korea had to contend with delicate issues related to its international standing which helped to orientate it toward engagement as a way to win over support for its cause. Ultimately though this effort failed, only Cuba boycotted the games and North Korea found itself cornered. Coupled with the collapse of the Soviet Union and the death of Kim Il-sung, North Korea would find itself on the path toward building nuclear weapons as a way to strengthen its international position.

\footnotetext{
${ }^{35}$ Pinkston, Daniel: "Why Declaring an End to the Korean War is More Complicated than you Might Think," NK News, November 12, 2018.
} 


\section{Bibliography}

Allen, Robert C: "The Rise and Decline of the Soviet Economy", The Canadian Journal of Economics / Revue Canadienne D'Economique, vol. 34, no. 4, (November, 2001), pp. 859-881.

Barrass, Gordon: “Able Archer 83: What Were the Soviets Thinking?" Survival, vol. 58, no. 6, (Novemeber 2016), pp. 7-30.

Buzo, Adrian. (1999): The Guerrilla Dynasty: Politics and Leadership in North Korea, London, I.B. Tauris.

Clifford, Mark. (1998): Troubled Tiger: Businessmen, Bureaucrats and Generals in South Korea, Armonk, M.E. Sharpe.

Eberstadt, Nicholas: "Western Aid: The Missing Link for North Korea's Economic Revival", in Snyder, Scott and Park, Kyung-Ae (eds.) (2013): North Korea in Transition: Politics, Economy, and Society, Lanham, Rowman and Littlefield Publishers, pp. 119-152.

Hoffman, David. (2009): The Dead Hand: The Untold Story of the Cold War Arms Race and Its Dangerous Legacy, New York, Anchor Books.

Im, Hyung Baeg: "The Origins of the Yushin Regime: Machiavelli Unveiled", in Vogel, Ezra F. and Kim, Byung-Kook (eds.) (2011): The Park Chung Hee Era: The Transformation of South Korea, Cambridge, Harvard University Press, pp. 233-261.

Jackson, Van. (2018): On the Brink: Trump, Kim, and the Threat of Nuclear War, Cambridge, Cambridge University Press.

Jameson, Sam: "Bomb Kills 5 in Seoul; North Koreans Blamed", Los Angeles Times, September 15, 1986.

Kristof, Nicholas: "North Korea Bids Hello to the World”, New York Times, July 1, 1989.

Lankov, Andrei. (2013): The Real North Korea: Life and Politics in the Failed Stalinist Utopia, Cambridge, Cambridge University Press.

Lewis, Jeffrey: “North Korea's Nuclear Disappearing Act”, National Interest, September 10, 2018.

Meeting between the National Olympic Committees of the ROK and of the DPRK held under the Aegis of the International Olympic Committee, at https://digitalarchive.wilsoncenter.org/document/113455.

Ming, Liu: "Changes and Continuities in Pyongyang's China Policy", in Snyder, Scott and Park, Kyung-Ae (eds.) (2013): North Korea in Transition: Politics, Economy, and Society, Lanham, Rowman and Littlefield Publishers, p. 211-238.

Oberdorfer, Don. (1997): The Two Koreas: A Contemporary History, London, Little, Brown.

Oh, Kangdon: "North Korea's Response to the World: Is the Door Ajar?", Rand Corporation, (January 1990), at https://www.rand.org/pubs/papers/P7616.html.

Paik, Haksoon: "Changes and Continuities in Inter-Korean Relations", in Snyder, Scott and Park, Kyung-Ae (eds.) (2013): North Korea in Transition: Politics, Economy, and Society, Lanham, Rowman and Littlefield Publishers, pp. 239-260.

Pinkston, Daniel: "Why Declaring an End to the Korean War is More Complicated than you Might Think," NK News, November 12, 2018.

Sebestyen, Victor. (2009): Revolution 1989: The Fall of the Soviet Empire, London, Weidenfeld \& Nicholson. 
Tertitskiy, Fyodor: "How Kim Il Sung broke free from the Soviet Union," NK News, March 19, 2019.

Wingfield-Hayes, Rupert: "The North Korean Spy who Blew up a Plane," BBC News, 22 April, 2013. 